\title{
Front Matter: Volume 11787
}

, "Front Matter: Volume 11787," Proc. SPIE 11787, Automated Visual Inspection and Machine Vision IV, 1178701 (30 June 2021); doi: $10.1117 / 12.2603217$

SPIE. Event: SPIE Optical Metrology, 2021, Online Only 


\title{
PROCEEDINGS OF SPIE
}

\section{Automated Visual Inspection and Machine Vision IV}

\author{
Jürgen Beyerer \\ Michael Heizmann \\ Editors
}

21-25 June 2021

Online Only, Germany

Sponsored by

SPIE

Cooperating Organisations

European Optical Society

German Scientific Laser Society (Wissenschaftliche Gesellschaft Lasertechnik e.V.)

Published by

SPIE 
The papers in this volume were part of the technical conference cited on the cover and title page. Papers were selected and subject to review by the editors and conference program committee. Some conference presentations may not be available for publication. Additional papers and presentation recordings may be available online in the SPIE Digital Library at SPIEDigitalLibrary.org.

The papers reflect the work and thoughts of the authors and are published herein as submitted. The publisher is not responsible for the validity of the information or for any outcomes resulting from reliance thereon.

Please use the following format to cite material from these proceedings:

Author(s), "Title of Paper," in Automated Visual Inspection and Machine Vision IV, edited by Jürgen Beyerer, Michael Heizmann, Proc. of SPIE 11787, Seven-digit Article CID Number (DD/MM/YYYY); (DOI URL).

ISSN: 0277-786X

ISSN: 1996-756X (electronic)

ISBN: 9781510644083

ISBN: 9781510644090 (electronic)

Published by

SPIE

P.O. Box 10, Bellingham, Washington 98227-0010 USA

Telephone +1 3606763290 (Pacific Time)

SPIE.org

Copyright @ 2021 Society of Photo-Optical Instrumentation Engineers (SPIE).

Copying of material in this book for internal or personal use, or for the internal or personal use of specific clients, beyond the fair use provisions granted by the U.S. Copyright Law is authorized by SPIE subject to payment of fees. To obtain permission to use and share articles in this volume, visit Copyright Clearance Center at copyright.com. Other copying for republication, resale, advertising or promotion, or any form of systematic or multiple reproduction of any material in this book is prohibited except with permission in writing from the publisher.

Printed in the United States of America by Curran Associates, Inc., under license from SPIE.

Publication of record for individual papers is online in the SPIE Digital Library.

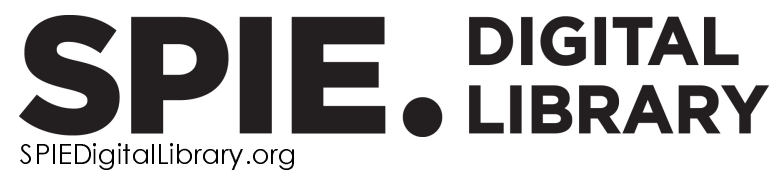

Paper Numbering: A unique citation identifier (CID) number is assigned to each article in the Proceedings of SPIE at the time of publication. Utilization of CIDs allows articles to be fully citable as soon as they are published online, and connects the same identifier to all online and print versions of the publication. SPIE uses a seven-digit CID article numbering system structured as follows:

- The first five digits correspond to the SPIE volume number.

- The last two digits indicate publication order within the volume using a Base 36 numbering system employing both numerals and letters. These two-number sets start with $00,01,02,03,04$, $05,06,07,08,09,0 A, 0 B \ldots$ OZ, followed by 10-1Z, 20-2Z, etc. The CID Number appears on each page of the manuscript. 


\section{Contents}

MACHINE LEARNING AND CLASSIFICATION

1178703 Data augmentation and pre-trained networks for extremely low data regimes unsupervised visual inspection (Invited Paper) [1 1787-1]

1178704 On evaluating deep learning-based optical flow methods for gas velocity estimation with optical gas imaging cameras [1 1787-2]

$1178705 \quad$ Explainability of deep learning classifier decisions for optical detection of manufacturing defects in the automated fiber placement process [1 1787-3]

1178706 Evaluation of thermography-based automated delamination and cavity detection in concrete bridges [1 1787-4]

1178707 Sequential concrete crack segmentation using deep fully convolutional neural networks and data fusion [11787-5]

\section{IMAGE-BASED MEASUREMENT TECHNOLOGY}

1178708 The effects of pattern screen surface deformation on deflectometric measurements: a simulation study [1 $1787-6]$

$1178709 \quad$ Multimodal measurement system for road analysis and surveying of road surroundings [1 1787-7]

11787 OA Irritation-free optical 3D-based measurement of tidal volume [1 1787-8]

11787 OB A GPU-based ray tracing approach for the prediction of multireflections on measurement objects and the a priori estimation of low-reflection measurement poses [11787-9]

11787 OD Experimental setup for fast VIS-NIR spectroscopy measurements in deflagrations [1 $1787-11]$

\section{POSTER SESSION}

11787 OE Classification of municipal solid waste using deep convolutional neural network model applied to multispectral images [1 1787-12]

11787 OG Qualification of holistic and generic camera-system calibration by fringe projection [1 1787-14]

$11787 \mathrm{OH} \quad$ Vision threads: a novel approach to generic camera calibration [1 1787-15] 
$11787 \mathrm{O} \quad$ Effective deep learning training method using blur and noise filter to detect defect in TFT-LCD PAD [11787-16]

11787 OK Improving light efficiency in multispectral imaging via complementary notch filters [1 1787-18]

11787 OL Deep learning for automated focus quality detection in wafer inspection [11787-19]

11787 OM Deep learning model and train method to increase the speed and accuracy in inline TFT-PAD area inspection [1 1787-20]

$11787 \mathrm{ON} \quad$ Nonlinear response of high speed infrared electronic devices: calibration for high temperatures [11787-21]

11787 OP Automated visual inspection of fabric image using deep learning approach for defect detection [1 1787-23]

11787 OR Development of a smartphone-based augmented reality device for industrial tasks [1 1787-25]

11787 OS Comparison of Unet and Mask R-CNN for impact damage segmentation in lock-in thermography phase images [1 1787-26] 